\title{
KAJIAN SINTAKSIS PADA NOVEL SANG PENCURI WARNA KARYA YERSITA
}

\author{
Cahyo Hasanudin \\ Fakultas Pendidikan Bahasa dan Seni, IKIP PGRI Bojonegoro \\ email: cha.sanu.88@gmail.com
}

\begin{abstract}
This study aims to describe the form of 1) phrase, 2, clause, and 3) sentence on novel of Sang Pencuri Warna by Yersita. This research is a qualitative descriptive study. Data collection using documentation techniques by applying strategis read, listen, and take note. Data analysis using content analysis Miles and Huberman. The result of the research shows 1) the existence of phrase form based on the relationship between the element and the core element of the word type, 2) the existence of positive and negative clauses, 3) the existence of the phrase based on pronunciation, grammatical structure, function or content, element, arrangement, presentation style (rhetoric), and the subject.
\end{abstract}

Keywords: Phrase, Clause, Sentence, Novel

\begin{abstract}
Abstrak
Penelitian ini bertujuan mendeskrispikan bentuk 1) frasa, 2, Klausa, dan 3) kalimat pada Novel Sang Pencuri Warna karya Yersita. Penelitian ini merupakan penelitian deskripstf kualitatif. Pengumpulan data menggunakan teknik dokumentasi dengan menerapkan strategi baca-cimakcatat. Analisis data menggunakan content analysis Miles dan Huberman. Hasil penelitian menunjukkan 1) adanya bentuk frasa berdasar hubungan antar unsur dan unsur inti jenis kata, 2) adanya bentuk klausa positif dan negatif, 3) adanya kalimat berdasar pengucapan, struktur gramatikal, fungsi atau isi, unsur, susunan, gaya penyajian (retorik), dan subjek
\end{abstract}

Kata kunci: Frasa, Klausa, Sentence, Novel

\section{PENDAHULUAN}

Novel Sang Pencuri Warna merupakan novel bernapas religi yang ditulis oleh Yersita pada November 2016. Novel ini diterbitkan oleh Diva Press dengan nomor ISBN 9786023912681. Novel ini menceritakan tentang Nara yang memiliki masalah dengan papanya, dia mengajukan mutasi agar ada alasan untuk jauh dari rumah. Di sekolah baru, dia menemukan banyak hal, termasuk masalah pelik. Kepala sekolah aneh, guru yang korupsi, guru honor yang malas, siswa yang terpaksa berhenti sekolah. Namun, yang lebih gawat adalah perhatiannya kini telah tercuri oleh sosok bernama Musa. Warna hari-harinya ditentukan oleh keberadaan Musa. Hanya saja, laki-laki itu terlalu saleh. Nara merasa Musa berada di luar jangkuan.
Di lain pihak, Musa tidak ingin terlalu berlebihan menanggapi Nara. Perhatian Nara dan kepedulian selama ini, menurutnya hanya karena rasa kasihan belaka.

Keindahan isi yang ditulis oleh pengarang ternyata tidak berhenti hanya sebatas pada alur dan konfik saja. Namun, di sisi lain, keindahannya dapat dilihat dari rangkaian kata-kata yang disusun secara rapi dan komunikatif sehingga dapat dikaji dari aspek kebahasaan, yaitu salah satunya adalah dengan kajian sintaksis.

Kajian sintaksis lahir atas jasa Chomsky (1957). Ia selanjutnya disebut sebagai bapak linguist pertama yang mengenalkan kajian sintaksis melalui sebuah bukunya yang berjudul "Syntactic Structure" buku itu selanjutnya disebut 
dengan istilah generative grammar. Kajian sintaksis dapat dikategorikan sebagai salah satu cabang ilmu bahasa yang mengkaji seluk beluk frasa, klausa, dan kalimat. Hal ini diperkuat oleh pendapat Parker and Riley (2005: 53) "Syntax is the study of phrases, clauses, and sentences". Selain itu, Ramlan (2005: 18) mengatakan bahwa sintaksis merupakan cabang ilmu bahasa yang membahas wacana, kalimat, klausa, dan frasa. Selajutnya Fromkin dan Rodman (1983: 200) mempertegas bahwa sintaksis itu bagian dari ilmu bahasa yang mengkaji struktur kalimat.

Hal senada juga diungkap oleh Ba'dulu dan Herman (2005: 44) bahwa sintaksis adalah telaah tentang struktur kalimat. Selain itu, Kridaklasana (2001: 199) menyatakan bahwa sintaksis ialah cabang linguistik yang mempelajari pengaturan dan hubungan antara kata dan kata,atau antara kata dan satuan-satuan yang lebih besar, atau antar satuan yang lebih besar itu di dalam bahasa. Artinya sintaksis itu ialah cabang ilmu bahasa yang mempelajari bagaimana pengaturan dan hubungan kata-kata dalam membentuk frasa, klausa, dan kalimat.

Berdasar pengertian sintaksis dari beberapa pakar tersebut. Perlu diketahui bahwa kajian ilmu sintaksis meliputi bentuk frasa, klausa, dan kalimat.

Frasa dapat dipahami sebagai bentuk gabungan kata yang memiliki satu fungsi. Hal ini sejalan dengan pendapat Permana (2010: 1376) bahwa frasa itu adalah unsur klausa yang terdiri dua kata atau lebih yang tidak melampaui batas fungsi yaitu subjek dan predikat atau dengan arti lain frasa adalah satuan gramatikal yang terdiri dari dua kata atau lebih yang tidak melebihi batas fungsi unsur klausa subjek dan predikat. Untuk lebih memahamkan bentuk frasa, dapat dilihat contoh berikut. di tanah air (Mahendra, 2017: 4)

Ras Etnis(Santoso,2017:4)
Dua Bulan (Dahlan: 2017: 4)

Ketiga contoh tersebut merupakan bentuk frasa, hal ini dapat dengan mudah ditentukan bahwa kata-kata yang tersusun tersebut merupakan unsurnya, tetapi apabila frasa itu terdiri dari tiga kata atau lebih, maka harus diperhatikan adanya prinsip hierarki dalam bahasa. Pada frasa di tanah air apabila dibuat diagramnya maka akan tampak seperti berikut.

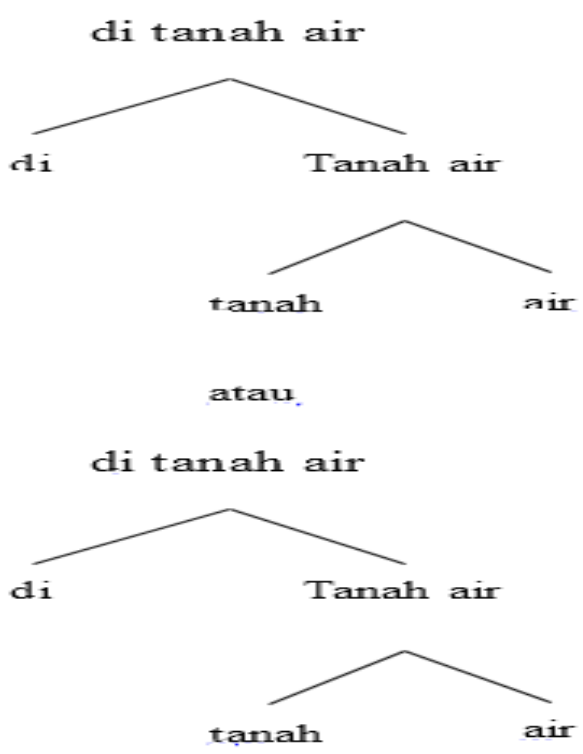

Jadi Frasa di tanah air dibangun dari frasa di tanah dan kata air, atau bisa juga kata $d i$ dengan frasa tanah air, namun kedua model ini secara hieraki tidak melewati batas fungsi frasa.

Frasa ras etnis dan dua bulan cukup jelas jika disusun dalam sebuah hierarki, pasalnya frasa ini hanya tersusun atas dua kata, frasa ras etnis terdiri dari kata ras dan etnis, serta frasa dua bulan terdiri dari kata dua dan bulan. Ketiga contoh ini merupakan jenis frasa, karena dilihat dari ciri-ciri frasa bahwa kata tersebut mampu disisipi konjungsi atau tidak mengalami perubahan makna. Hal inilah merupakan pembeda antara frasa dengan kata majemuk. 
Klausa dapat diartikan sebagai satu kesatuan fungsi sintaksis yang minimal memiliki fungsi $\mathrm{S}$ dan $\mathrm{P}$, serta fungsi sintaksis ini sangat berpotensi menjadi bentuk yang lebih tinggi (kalimat). Pendapat ini didukung oleh Ruliati (2015: 4) bahwa klausa adalah satuan gramatikal yang berupa kelompok kata, sekurangkurangnya terdiri atas subjek dan predikat dan berpotensi menjadi sebuah kalimat. Contoh klausa adalah sebagai berikut.

$\frac{\text { Jiwa keadaban }}{\mathrm{S}} \quad \frac{\text { Selalu lahir }}{\mathrm{P}}$

Hukum dijadikan (Ida, 2017: 4). Klausa ini jika dipolakan berdasarkan fungsi sintaksis adalah

$$
\frac{\text { hukum }}{\mathrm{S}} \quad \frac{\text { dijadikan }}{\mathrm{P}}
$$

Presiden Hosni Mubarak mengundurkan diri (Lesmana, 2017:4). Klausa ini jika dipolakan berdasarkan fungsi sintaksis adalah

$\frac{\text { Presiden Hosni Mubarok }}{\mathrm{S}} \quad \frac{\text { mengundurkan diri }}{\mathrm{P}}$

Ketiga contoh klausa yang telah dipaparkan di atas memiliki pola S P, dari pola yang dimiliki inilah, ketiga klausa tersebut berpotensi sekali untuk menjadi sebuah kalimat. Ketiga klausa tersebut belum mampu disebut sebagai kalimat karena belum adanya intonasi akhir. Pada klausa Jiwa keadaban selalu lahir, masih dipertanyakan selalu lahir di mana? Klausa Hukum dijadikan, masih dipertanyakan juga, yaitu mau dijadikan apa? Klausa Presiden Hosni Mubarak mengundurkan diri, masih dipertanyakan mengundurkan diri dari jabatan apa? Nah, pertanyaanpertanyaan inilah yang menyebabkan ketiga contoh di atas masuk ke dalam klausa karena belum ada informasi lengkap atau belum adanya intonasi akhir.

Kalimat adalah kajian sintaksis yang lebih tinggi dari klausa dan frasa yang memiliki fungsi minimal $\mathrm{S}$ dan $\mathrm{P}$ serta memiliki intonasi akhir. Keraf (1995: 57) menjelaskan bahwa kalimat adalah sebuah struktur yang masing-masingnya merupakan kesatuan yang dibentuk dari suatu bagian. Struktur itu sendiri merupakan hubungan antara kesatuan dan bagian-bagian itu sendiri. Alwi (2003: 322) menambahkan bahwa pola kalimat itu dimulai dari S P, S P O, S P Pel, S P K, dan S P O K. Di sisi lain Fitriani (2015: 129) menyatakan pendapat bahwa kalimat itu adalah salah satu faktor yang menunjang sebuah karangan efektif bagi pembaca karena kalimat membawa pembaca berkenalan isi suatu tulisan. Berikut dijelaskan beberapa contoh kalimat.

Krisis itu menimbulkan disorientasi. (Azra, 2016:6). Kalimat ini memiliki pola sebagai berikut

$\frac{\text { Krisis itu }}{\mathrm{S}} \quad \frac{\text { menimbulkan }}{\mathrm{P}} \quad \frac{\text { disorientasi }}{\mathrm{O}}$

NASA mencatat suhu rerata bumi pada februari. 2016 (Wahyono, 2017:4). Klausa ini jika dipolakan berdasarkan fungsi sintaksis adalah

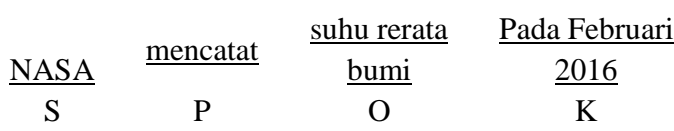

Kedua contoh di atas termasuk bentuk kalimat karena memiliki pola yang lengkap dan sudah memiliki intonasi akhir. Kedua kalimat ini termasuk ke dalam kalimat tunggal karena memiliki satu susunan pola.

Guru perlu diayomi dan diadvokasi. (Abduhzen, 2016:6). Kalimat ini memiliki pola sebagai berikut

$\frac{\text { Guru }}{\mathrm{S}} \quad \frac{\text { perlu diayomi dan diadvokasi }}{\mathrm{O}}$

Nampak jelas adanya pelesapan fungsi $S$ karena subjek pada kalimat tersebut menggunakan kata yang sama sehingga tidak perlu ditulis ulang pada klausa selanjutnya.

Selain mengkaji frasa, klausa, dan kalimat, dalam kajian sintaksis juga dikenal dengan adanya istilah fungsi, kategori, dan 
peran sintaksis. Berikut penjelasan dari ketiga kategori tersebut.

Aku melihat Dilan. (Baiq, 2015: 144). Kalimat ini jika didistribusikan berdasarkan fungsi, kategori, dan peran sintaksis adalah sebagai berikut.

Tabel 1. Fungsi, Kategori, dan Peran

Sintaksis

\begin{tabular}{lccc}
\hline Kalimat & $\underline{\text { Aku }}$ & $\underline{\text { Melihat }}$ & $\underline{\text { Dia }}$ \\
\hline Fungsi & $\mathrm{S}$ & $\mathrm{P}$ & $\mathrm{O}$ \\
Kategori & pronomina & verba & nomina \\
Peran & pelaku & perbuatan & penderita \\
\hline
\end{tabular}

Melati menyetop bus di jalan raya (Fajarwati, 2017:93). Kalimat ini jika didistribusikan berdasarkan fungsi, kategori, dan peran sintaksis adalah sebagai berikut.

Tabel 2. Fungsi, Kategori, dan Peran Sintaksis

\begin{tabular}{|c|c|c|c|c|}
\hline Kalimat & $\underline{\text { Melati }}$ & menyetop & $\underline{\text { bus }}$ & $\frac{\text { di jalan }}{\underline{\text { raya }}}$ \\
\hline Fungsi & $\mathrm{S}$ & $\mathrm{P}$ & $\mathrm{O}$ & $\mathrm{K}$ \\
\hline Kategori & nomina & verba & Nomina & preposisi \\
\hline Peran & pelaku & perbuatan & Penderita & $\begin{array}{l}\text { makna } \\
\text { tempat }\end{array}$ \\
\hline
\end{tabular}

\section{METODE PENELITIAN}

Metode penelitian yang digunakan adalah deskripsi kualitatif dengan teknik pengumpulan data menggunakan teknik baca-simak-catat. Sumber data penelitian ini adalah Sang Pencari Warna (2016) karya Yersita. Selanjutnya data dianalisis dengan metode content analysis Miles dan Huberman (2007: 16) yang digambarkan sebagai komponen-komponen analisis data model alir yang terdiri dari tiga alur kegiatan secara bersamaan, yaitu 1) reduksi data; 2) penyajian data; dan 3) penarikan simpulan/verifikasi. komponen-komponen analisis data: Model Alir mempunyai tiga komponen yang saling terjalin dengan baik, yaitu sebelum, selama dan sesudah pelaksanaan pengumpulan data. Pada tahap reduksi data, peneliti mencatat kemudian menyederhanakan data sehingga hanya data yang mengandung frasa, klausa, dan kalimat yang dipilih. Pada tahap sajian data, peneliti menyusun kemudian menganalisis data sehingga diperoleh deskripsi tentang frasa, klausa, dan kalimat serta kejelasannya. Pada tahap simpulan/verifikasi, peneliti membuat simpulan tentang bentuk frasa, klausa, dan kalimat yang telah tersaji. Simpulan ini masih memerlukan adanya verifikasi sehingga hasil yang diperoleh benar-benar valid. Pada penelitian ini, peneliti melakukan kembali langkah-langkah di atas mengenai bentuk frasa, klausa, dan kalimat yang ada pada Sang Pencuri Warna karya Yersita. Teknik pengujian keabsahan penelitian menggunakan triangulasi teori dari beberapa pakar bahasa dan triangulasi sumber dengan menggunakan artikel hasil penelitian.

\section{HASIL DAN PEMBAHASAN}

Hasil penelitian kajian sintaksis pada novel Sang Pencari Warna karya Yersita dapat ditunjukkan pada bentuk frasa, klausa, dan kalimat. Bentuk Frasa pada novel Sang Pencuri Warna karya Yersita dapat dibedakan berdasarkan beberapa pengelompokan, yaitu berdasarkan hubungan antarunsurnya, jenis kata pada unsurnya, dan berdasarkan makna.

Berdasarkan hubungan antarunsur frasa dibedakan menjadi: (1) Frasa Endosentris adalah frasa yang memiliki distribusi sama dengan satu di antara unsurnya atau dengan semua unsurnya. Artinya, satu di antara unsur dalam frasa tersebut dapat menggantikan kedudukan frasa secara keseluruhan. Frasa endosentris terbagi menjadi tiga, yaitu frasa endosentris atributif, frasa endosentris koordinatif, dan frasa endosentris apositif (Ramlan, 2005: 142). (2) Frasa Koordinatif adalah Frasa ini terdiri atas unsur-unsur yang memiliki kedudukan setara. Kesetaraannya itu dibuktikan oleh kemungkinan unsur-unsur 
itu dihubungkan dengan kata penghubung dan atau atau (Supriyadi, 2014: 12). Berdasarkan analisis novel Sang Pencuri Warna karya Yersita dapat ditemukan contoh frasa koordinatif misalnya: "Emak bapak Musa sedang marah" (Yersita, 2016: 63). Pada contoh Emak bapak temasuk golongan frasa koordinatif karena unsur Emak bapak dapat dihubungkan dengan kata penghubung dan atau atau. (3) Frasa Atributif adalah frasa yang mengandung hanya satu inti Rahmat (2012). Berdasarkan analisis novel Sang Pencuri Warna karya Yersita dapat ditemukan contoh frasa Atributif misalnya, "Meja Panjang" (Yersita, 2016: 8). Contoh "meja panjang" merupakan unsur pusat sehingga tidak bisa disisipi kata penghubung apapun, sehingga contoh tersebut merupakan bentuk dari frasa atributif. (4) Frasa apositif adalah frasa endosentris berinduk banyak yang secara luar bahasa komponennya menunjuk pada maujud yang sama (Arifin dan Junaiyah, 2008: 25). Berdasarkan analisis novel Sang Pencuri Warna karya Yersita dapat ditemukan contoh frasa apositif misalnya, "Kepala sekolah namanya sangat mudah untuk diingat, Suratman" (Yersita, 2016: 7) Pada unsur Suratman merupakan unsur pusat, sedangkan unsur Kepala sekolah namanya sangat mudah untuk diingat merupakan unsur aposisi apositif. Sehingga, unsur Suratman mampu menggantikan unsur kepala sekolah. (5) Frasa eksosentrik adalah frasa yang tidak memiliki unsur langsung yang dapat menggantikan posisinya di dalam kalimat (Rosliana, 2015: 54). Berdasarkan analisis novel Sang Pencuri Warna karya Yersita dapat ditemukan contoh frasa eksosentris misalnya, "di rumah" (Yersita, 2016: 18). Pada contoh di rumah, memiliki unsur satu kesatuan karena karena memiliki distribusi yang sama.

Berdasarkan unsur inti jenis kata frasa dibedakan menjadi, (1) Frasa Verba yang menurut Chaer (2009: 138) adalah sebuah frasa yang mengisi fungsi predikat pada sebuah klausa maupun kalimat. Berdasarkan analisis novel Sang Pencuri Warna karya Yersita dapat ditemukan contoh frasa verba sebagai berikut: "Selalu mengantar makanan" (Yersita, 2016: 39). Pada kata yang dicetak miring yaitu mengantar termasuk golongan verb (kata kerja). Oleh karena itu, kata mengantar termasuk frasa verba. (2) Frasa Nomina adalah frasa inti (induk) berupa bentuk nomina. Berdasarkan analisis novel Sang Pencuri Warna karya Yersita dapat ditemukan contoh frasa nomina sebagai berikut: "Rumah Tua" (Yersita, 2016: 15). Kata yang dicetak miring yaitu rumah, termasuk golongan nomina (kata benda). Oleh karena itu, kata Rumah termasuk frasa nomina. (3) Frasa Adjektiva adalah kelompok kata yang dibentuk dengan kata sifat atau keadaan sebagai inti (yang diterangkan) dengan menambahkan kata lain yang berfungsi menerangkan seperti agak, dapat, harus, kurang, lebih, paling, dan sangat. Berdasarkan analisis novel Sang Pencuri Warna karya Yersita dapat ditemukan contoh frasa adjektiva sebagai berikut: "Sangat penakut" (Yersita, 2016: 11), kata yang dicetak miring yaitu penakut termasuk golongan adjektiva (kata sifat). Oleh karena itu, kata penakut dan romantis termasuk frasa adjektiva. (4) Frasa Numeralia adalah Frasa yang memiliki distribusi yang sama dengan kata bilangan atau numeralia (Ramlan, 2005: 162). Berdasarkan analisis novel Sang Pencuri Warna karya Yersita dapat ditemukan contoh frasa numeralia sebagai berikut: "Delapan" ruang kelas (Yersita, 2016: 7), kata yang dicetak miring yaitu delapan dan satu termasuk golongan numeralia (kata bilangan). Oleh karena itu, kata delapan dan satu termasuk frasa numeralia.

Unsur yang kedua adalah klausa. Jenis klausa pada novel Sang Pencuri 
Warna karya Yersira berupa klausa positif dan klausa negatif. Klausa positif ialah klausa yang ditandai tidak adanya unsur negasi yang menegatifkan P. Berdasarkan analisis novel Sang Pencuri Warna karya Yersira dapat ditemukan contoh klausa positif sebagai berikut: "Papa sedang merindukan kakak" (Yersita, 2016: 87). Klausa ini terdiri atas satu frasa, yaitu sedang merindukan. Unsur papa menduduki fungsi $S$, frasa sedang merindukan menduduki fungsi $\mathrm{P}$, dan unsur kakak menduduki fungsi O. Pada klausa ini tidak terdapat unsur negasi yang menegatifkan $\mathrm{P}$. Dengan demikian, klausa Papa sedang merindukan kakak disebut klausa positif. Klausa negatif ialah klausa yang ditandai adanya unsur negasi yang menegatifkan $P$. Berdasarkan analisis novel Sang Pencuri Warna karya Yersira dapat ditemukan contoh klausa negatif sebagai berikut: "Musa seperti tidak membutuhkan uang tersebut" (Yersita, 2016: 95). Pada kalimat tidak membutuhkan terlihat jelas bahwa fungsi $\mathrm{P}$ mengandung negasi, sehinga contoh ini termasuk jenis klausa negatif.

Bentuk kalimat yang ada pada novel Sang Pencuri Warna karya Yersita dapat diklasifikasikan berdasarkan pengucapan, struktur gramatikal, dan fungsi (isi). Kalimat Berdasarkan pengucapan terbagi atas dua, yaitu kalimat langsung dan kalimat tidak langsung. Kalimat langsung dapat diartikan sebagai kalimat yang diucapkan secara langsung oleh penutur. Berdasarkan hasil analisis pada novel Sang Pencuri Warna karya Yersira dapat ditemukan contoh kalimat langsung sebagai berikut: "Kakak sedang jatuh cinta, ya?" tanya Mira (Yersita, 2016: 84), pada kalimat tersebut itu benar-benar sesuai dengan yang diucapkan oleh si pembicara maka dari itu bisa disebut kalimat langsung. Kalimat tidak langsung dapat didefinisikan sebagai kalimat yang diucapkan oleh pihak kedua, pihak kedua menyalin apa yang diucapkan oleh pihak pertama. Kalimat tidak langsung dapat dicirikan dengan penggunaan kata "bahwa" dan tanpa penggunaan tanda petik (“......”). Berdasarkan hasil analisis pada novel Sang Pencuri Warna karya Yersira dapat ditemukan kalimat tidak langsung. Bu Yuni terus bercerita jika dia sudah lelah menjadi bendahara (Yersita, 2016: 153), Pada kalimat percakapan antara bu Yuni dengan tokoh aku, kemudian tokoh aku menceritakan atau memberitahukan kepada tokoh lain, dengan kata lain, apa yang diucapkan oleh orang pertama disalin oleh pihak kedua untuk diinformasikan kepada pihak ketiga. Kalimat inilah menandakan bahwa novel Sang Pencuri Warna karya Yersira mengandung kalimat tidak langsung.

Kalimat Berdasaran jumlah frasa atau struktur gramatikal terbagi atas dua, yaitu kalimat tunggal dan kalimat majemuk. (1) Kalimat tunggal adalah kalimat yang memiliki satu klausa atau satu konstituen Subjek-Predikat. Berdasarkan analisis novel Sang Pencuri Warna karya Yersira dapat ditemukan contoh kalimat tunggal sebagai berikut: "Musa sedang marah" (Yersita, 2016: 63), pada kalimat nomor tesebut terdapat satu klausa atau satu konstituen S$\mathrm{P}$ yaitu Musa berpola $\mathrm{S}$ sedangkan sedang marah berpola $\mathrm{P}$ maka disebut kalimat tunggal. (2) Kalimat majemuk adalah kalimat yang memiliki lebih dari satu klausa. Berdasarkan sifatnya, kalimat majemuk dapat dibedakan menjadi tiga jenis, yaitu, kalimat majemuk setara, bertingkat, dan campuran. Kalimat majemuk setara dapat diartikan sebagai kalimat yang terbentuk dari dua klausa yang seimbang serta ditandai dengan konjungsi dan, atau, tetapi. Berdasarkan analisis novel Sang Pencuri Warna karya Yersira dapat ditemukan contoh kalimat majemuk setara sebagai berikut: "Orangorang sudah siap dan menunggu" (Yersita, 
2016: 118), pada kalimat ditandai dengan konjungi dan. Jika dipola berdasarkan fungsinya adalah.

\begin{tabular}{|c|c|c|c|c|}
\hline Orang- & $\underline{\text { sudah }}$ & & orang- & \\
\hline orang & siap & dan & orang & menunggu \\
\hline $\mathrm{S}$ & $\mathrm{P}$ & $\begin{array}{c}\text { Kon } \\
\text { j. }\end{array}$ & $\mathrm{S}$ & $\mathrm{P}$ \\
\hline
\end{tabular}

Kalimat di atas sejatinya ada pelesapan fungsi $S$, fungsi $S$ yang menggunakan kata yang sama tidak perlu diulang pada kalimat majemuk setara, sehingga kalimat di atas memiliki pola SP SP. Kalimat majemuk bertingkat adalah kalimat yang hubungan pola-polanya tidak sederajat, salah satu pada bagian yang lebih tinggi kedudukannya disebut induk kalimat, sedangkan bagian yang lebih rendah kedudukannya disebut dengan anak kalimat (Putrayasa, 2009: 59). Berdasarkan analisis novel Sang Pencuri Warna karya Yersira dapat ditemukan contoh kalimat majemuk bertingkat sebagai berikut: "Musa pulang ngajar ketika ibu memasak nasi" (Yersita, 2016: 54), kalimat tersebut jelaslah tergolong sebagai kalimat majemuk bertingkat karena menggunakan konjungsi Ketika. Konjungsi ini merupakan penciri dari kalimat majemuk bertingkat. Apabila diuraikan berdasarkna fungsinya adalah sebagai berikut

$\frac{\text { Musa pulang ngajar }}{\mathrm{S}} \frac{\text { ketika }}{\text { Konj. }} \frac{\text { Ibu }}{\mathrm{S}} \frac{\text { memasak }}{\mathrm{P}} \frac{\text { nasi }}{\mathrm{O}}$ Kalimat ini memiliki pola serta dibangun oleh dua klausa, klausa Musa pulang ngajar sebagai induk kalimat, sedangkan klausa ketika ibu memasak nasi sebagai anak kalimat.

Kalimat majemuk campuran dapat diartikan sebagai bentuk kalimat yang memiliki tiga klausa atau gabungan dari kalimat majemuk setara dan bertingkat. Berdasarkan analisis novel Sang Pencuri Warna karya Yersira ditemukan bentuk kalimat majemuk campuran seperti berikut: "Setelah ia mendengar beberapa nasihat yang disampaikan dokter, Musa dan pamannya pulang" (Yersita, 2016: 247), kalimat tersebut dapat dikategorian kedalam kalimat majemuk campuran karena kalimat ini mengandung dua konjungsi, konjungsi setelah yang merupakan penciri dari kalimat majemuk bertingkat dan konjungsi dan sebagai penciri kalimat majemuk setara.

Kalimat ini memiliki pola dan terdiri dari tiga klausa, klausa pertama Setelah ia mendengar beberapa nasihat yang disampaikan dokter sebagai anak kalimat, dan klausa kedua Musa pulang, serta klausa ketiga dan pamannya pulang sebagai induk kalimat. Perlu diketahui lagi, bahwa induk kalimat Musa dan pamannya pulang ada pelesapan fungsi $\mathrm{P}$ karena menggunakan unsur yang sama, yaitu pulang, maka ada fungsi $\mathrm{P}$ yang dihilangkan. Sebenarnya klausa Musa dan pamannya pulang jika ditulis secara normal adalah musa pulang dan pamannya pulang.

Kalimat berdasarkan fungsi atau isi dibedakan menjadi empat yaitu, kalimat perintah, kalimat berita, kalimat tanya, dan kalimat seruan. Kalimat perintah dapat dijelaskan sebagai bentuk perintah dari penutur kepada mitra tutur. Berdasarkan analisis novel Sang Pencuri Warna karya Yersira dapat ditemukan contoh kalimat perintah sebagai berikut: "Pulanglah! Turuti semua keinginan orang tuamu, patuhi mereka, perintah musa, jangan pernah datang ke sini lagi (Yersita, 2016: 59), pada kalimat tersebut cukup jelas jika kalimat tersebut mengandung kalimat perintah, yaitu dengan kata pulanglah!. Hal ini sejalan dengan pendapat (Putrayasa, 2009: 31) bahwa Kalimat perintah adalah kalimat yang isinya menyuruh orang lain untuk melakukan sesuatu yang kita kehendaki. Kalimat berita dapat dikatakan sebagai kalimat yang memberikan informasi kepada orang lain atau kalimat yang mampu dijawab dengan pertanyaan "Askadimega" serta menggunakan tanda titik di akhir 
kalimat. Berdasarkan analisis novel Sang Pencuri Warna karya Yersira dapat ditemukan contoh kalimat berita sebagai berikut: "Andito sedang sakit malaria pak" (Yersita, 2016: 25), kalimat tersebut merupakan jawaban dari pertanyaan Sakit apa Andito? Sehingga jawaban dari pertanyaan tersebut harus menggunakan tanda titik diakhir kalimat yang disebut dengan kalimat berita. Kalimat tanya merupakan kalimat yang memanfaatkan kata tanya "Askadimega". Kalimat tanya dtandai dengan penggunaan tanta "?" pada akhir kalimat. Berdasarkan analisis novel Sang Pencuri Warna karya Yersira dapat ditemukan contoh kalimat tanya sebagai berikut: "Siapa laki-laki yang tampam itu, Nara?" (Yersita, 2016: 172), kalimat tersebut menggunakan kata tanya siapa, menanyakan bentuk kebenaran terhadap kondisi tokoh. Kalimat seruan adalah kalimat yang isinya mengungkapkan kekaguman perasaan dan diakhiri tana baca (!). Berdasarkan analisis novel Sang Pencuri Warna karya Yersira dapat ditemukan contoh kalimat seruan sebagai berikut: "Sungguh baik guru yang bernama musa itu!" (Yersita, 2016: 46), kalimat tersebut menunjukkan bentuk kekaguman kepada tokoh.

Kalimat berdasarkan unsurnya dibedakan menjadi dua yaitu, kalimat lengkap dan kalimat tidak lengkap. Kalimat lengkap merupakan kalimat yang memiliki susunan lengkap, yaitu setidaknya memiliki unsur S dan P. Berdasarkan analisis novel Sang Pencuri Warna karya Yersira dapat ditemukan contoh kalimat lengkap sebagai berikut: "Siswa-siswa mendengar petuah Musa" (Yersita, 2016: 77). Kalimat tersebut berpola S P O, dengan pola kalimat Siswasiswa memiliki fungsi $\mathrm{S}$ mendengar memiliki fungsi $\mathrm{P}$ petuah Musa memiliki fungsi $O$. Sehingga kalimat tersebut dapat dikatakan sebagai kalimat lengkap. Kalimat tidak lengkap dapat dikatakan sebagai kalimat yang tidak memiliki struktur klausa. Berdasarkan analisis novel Sang Pencuri Warna karya Yersira dapat ditemukan contoh kalimat tidak lengkap sebagai berikut: "Selamat pagi" (Yersita, 2016:26). Kalimat Selamat pagi tidak memiliki strutur klausa, sehingga kalimat ini merupakan bentuk kalimat tidak lengkap.

Kalimat berdasarkan susunan dibedakan menjadi dua yaitu, Inversi (kalimat terbalik), Versi (kalimat tidak terbalik).Kalimat Inversi (kalimat terbalik) adalah kalimat yang polanya tidak berurutan. Berdasarkan analisis novel Sang Pencuri Warna karya Yersira dapat ditemukan contoh kalimat inversi sebagai berikut: "Pernah aku terkaget-kaget (Yersita, 2016: 80). Kalimat tersebut memiliki susunan fungsi Pernah memiliki fungsi $\mathrm{P}$ aku memiliki fungsi $\mathrm{S}$ terkagetkaget memiliki fungsi Pel. Jadi cukuplah jelas bahwa kalimat tersebut tergolong kedalam kalimat inversi, di mana fungsi $\mathrm{P}$ mendahulu fungsi $\mathrm{S}$, jika dipola kalimat tersebut memiliki susuna P S Pel. Kalimat versi (kalimat tidak terbalik) adalah kalimat yang polanya beraturan. Berdasarkan analisis novel Sang Pencuri Warna karya Yersira dapat ditemukan contoh kalimat versi sebagai berikut: "Bu nara mengoreksi jawaban siswa" (Yersita, 2016: 32). Pada kalimat tersebut $\mathrm{Bu}$ nara memiliki fungsi $\mathrm{S}$ mengoreksi memiliki fungsi $\mathrm{S}$ jawaban siswa memiliki fungsi $\mathrm{O}$. Kalimat tersebut memiliki fungsi yang berurutan sesuai kaidah kebahasaan yaitu S P O, sehingga kedua kalimat ini dapat dikategorikan sebagai bentuk kalimat versi karena kedua kalimat ini tidak memiliki susunan balik ( $\mathrm{P}$ mendahului $S$ ).

Kalimat berdasarkan bentuk atau gaya penyajian dibedakan menjadi tiga yaitu, kalimat yang melepas, kalimat yang klimaks, kalimat yang berimbang. Kalimat melepas adalah jenis kalimat majemuk yang 
terdiri dari induk kalimat dan anak kalimat, dimana induk kalimat diletakkan di awal kalimat dan kemudian diikuti oleh anak kalimat. Berdasarkan analisis novel Sang Pencuri Warna karya Yersira dapat ditemukan contoh kalimat yang melepas sebagai berikut: "Musa menyapu ketika Nara sedang tidur" (Yersita, 2016: 207), kalimat tersebut menggambarkan adanya bentuk yang dilepas dari induk kalimatnya, yaitu klausa nara sedang tidur hal ini menandakan bahwa kalimat tersebut disajikan dengan gaya yang melepas, unsur anak kalimat seakan-anak dilepasakan begitu saja oleh pengarang dan kalaupun unsur ini tidak diucapkan atau dituliskan, kalimat ini juga sudah dapat dikatakan sebagai kalimat lengkap. Kalimat klimaks adalah kalimat yang diawali dari sebuah rincian dan kemudian diikuti oleh inti penting dari informasi. Berdasarkan analisis novel Sang Pencuri Warna karya Yersira dapat ditemukan contoh kalimat yang klimaks sebagai berikut: "Jika Musa ingat kejadian itu, ia semakin sedih" (Yersita, 2016: 174), Kalimat tersebut merupakan bentuk kalimat yang klimaks, hal ini dapat dilihat dari penulisan anak kalimat mendahului induk kalimat, gaya inilah selanjutnya disebut sebagai gaya berklimaks. Pembaca tidak akan dapat memahami kalimat (49) Jika Musa ingat kejadian itu secara utuh, jika pembaca tidak membaca induk kalimat dari kalimat tersebut. Induk kalimatlah letak dari klimaks itu berada, sehingga hal ini dapat dikatakan sebagai bentuk kalimat yang mengandung unsur ketegangan. Kalimat ini biasanya disusun dalam bentuk kalimat majemuk setara atau kalimat majemuk campuran. Gaya penyajian seperti ini ialah untuk memperlihatkan kesejajaran bentuk dan informasinya. Berdasarkan analisis novel Sang Pencuri Warna karya Yersira dapat ditemukan contoh kalimat berimbang sebagai berikut: "Laki-laki saleh itu memegang teguh prinsipnya dan benarbenar menjalankan syariat Islam secara konsisten" (Yersita, 2016: 193), Kalimat tersebut nampak menggunakan konjungsi dan, dilihat dari kunjungsi yang digunakan kalimat ini termasuk kalimat majemuk setara. Jadi, hal ini menandakan adanya hubungan yang seimbang karena strukturnya memperlihatkan kesejajaran yang sejalan dan dituangkan ke dalam model kalimat yang bersimetri.

Berdasarkan subjeknya, kalimat dibedakan atas dua bagian, yaitu: kalimat aktif dan kalimat pasif. Berikut penjelasan dari kedua jenis kalimat tersebut. Kalimat aktif dapat dipaham sebagai kalimat yang memiliki ciri fungsi $\mathrm{P}$ melakukan tindakan aktif, hal ini ditandai dengan adanya imbuhan me atau ber pada fungsi $P$ tersebut. Ditinjau dari segi predikatnya, kalimat aktif dapat dibedakan menjadi tiga jenis: (1) Kalimat aktif transitif adalah kalimat yang fungsi $\mathrm{P}$ nya mengandung imbuhan me selain itu, pada kalimat aktif transitif kehadiran fungsi $\mathrm{O}$ itu sangatlah penting. Berdasarkan analisis novel Sang Pencuri Warna karya Yersira dapat ditemukan contoh kalimat aktif transitif sebagai berikut: "Gebi menggendong bayi mungil" (Yersita, 2016: 222), Kalimat inimemiliki fungsi $\mathrm{S}$, menggendong memiliki fungsi $\mathrm{P}$. Fungsi $\mathrm{P}$ pada kata menggendong merupakan bentuk asal dari me- + gendong $=$ mengendong, sehingga kata ini mengandung imbuhan me, dan bayi mungil memiliki fungsi $O$. Tanpa ada frasa bayi mungil, maka unsur Gebi menggendong masih dalam tanda tanya, apa yang digendong Gebi?, dan ini harus dijawab lengkap, jika kalimat itu kalimat aktif transitif. (2) Kalimat aktif intransitif dapat diartikan sebagai kalimat yang tidak membutuhkan fungsi $\mathrm{O}$ pada susunan kalimat tersebut. Kehadiran fungsi $\mathrm{O}$ tidak berpengaruh terhadap makna dari kalimat tersebut, tanpa kehadiran $\mathrm{O}$ pun kalimat ini 
sudah mampu berdiri sendiri. Arti in pada kata intransitif merupakan serapan dari bahasa asing yang berarti tidak. Berdasarkan analisis novel Sang Pencuri Warna karya Yersira dapat ditemukan contoh kalimat aktif intransitif sebagai berikut: "Ibunya tinggal dirumah tua" (Yersita, 2016: 15), kalimat inimemiliki fungsi $S$ tinggal memiliki fungsi $\mathrm{P}$ dirumah tua memiliki fungsi $\mathrm{K}$, kalimat tersebut, tanpa hadirnya fungsi $\mathrm{O}$, kalimat ini sudah mampu berdiri sendiri dan dipahami oleh pembaca. (3) Kalimat aktif semitransitif dapat diartikan sebagai kalimat yang menghadirkan fungsi Pelengkap setelah fungsi P. Kalimat aktif semitransitif sejatinya sama dengan kalimat aktif transitif, hanya saja, jika di kalimat aktif transitif wajib menghadirkan fungsi $\mathrm{O}$ dan berkategori benda, sedang pada kalimat aktif semitransitif wajib menghadirkan fungsi pelengkap, hal ini dapat ditandai dengan adanya imbuhan ber pada fungsi P. Berdasarkan analisis novel Sang Pencuri Warna karya Yersira dapat ditemukan contoh kalimat aktif intransitif sebagai berikut: "Musa selalu berdoa dalam setiap sujudnya" (Yersita, 2016: 267). Kata Musa memiliki fungsi $\mathrm{S}$ selalu berdoa memiliki fungsi $\mathrm{P}$ dalam setiap sujudnya memiliki fungsi Pel. Hadirnya fungsi pelengkap menandakan kalimat ini tergolong ke dalam kalimat aktif semitransitif, selain itu dapat dilihat dari fungsi $\mathrm{P}$ yang mengandung imbuhan ber- bukan me-.

Kalimat pasif dapat diartikan sebagai bentuk kalimat yang fungsi $\mathrm{O}$ sebagai pelaku dengan adanya fungsi S. Kalimat ini dapat diingat dengan melihat fungsi $P$ yang mengandung imbuhan di- dan ter $\neg$-. Pada umumnya kalimat pasif mampu diubah menjadi kalimat aktif dengan menukar susunan fungsi $\mathrm{S}$ dan $\mathrm{O}$ nya dan membalik imbuhan di- menjadi me- pada fungsi $\mathrm{P}$ nya. Berdasarkan analisis novel Sang Pencuri Warna karya Yersira dapat ditemukan contoh kalimat pasif sebagai berikut:"Tindakan itu dilakukan sampai beberapa menit" (Yersita, 2016: 115). Tindakan itu memiliki fungsi S, dilakukan memiliki fungsi $\mathrm{P}$, sampai beberapa menit memiliki fungsi $O$. Ciri yang paling nampak jika kalimat ini tergolong ke dalam kalimat pasif adalah melihat dari fungsi $\mathrm{P}$ yang mengandung imbulan di-, selain itu, adanya fungsi $\mathrm{O}$ yang dapat ditukar menjadi fungsi $\mathrm{S}$ menandakan kalimat ini adalah kalimat pasif. Adapun penjelasannya seperti berikut

Tindakan itu dilakukan sampai beberapa menit $(S P O) \rightarrow$ bentuk kalimat pasif

Sampai beberapa menit melakukan tindakan itu $(\mathrm{SPO}) \rightarrow$ bentuk kalimat aktif

Hasil penelitian tentang bentukbentuk kalimat ini sejalan dengan temuan Septianingtias (2015: 42-29) bahwa kumpulan dongeng Gadis Korek Api karya H.C. Andersen menunjukkan adanya pola kalimat dan kategori berdasarkan pemakaiannya, adanya pola kalimat perintah dan pola kalimat konektor atau konjungsi, dan yang terakhir adanya bentuk kalimat majemuk.

\section{SIMPULAN}

Penelitan ini dapat disimpulkan bahwa novel Sang Pencuri Warna karya Yersira terdapat 1) adanya bentuk frasa berdasar hubungan antar unsur dan unsur inti jenis kata, 2) adanya bentuk klausa positif dan negatif, 3) adanya kalimat berdasar pengucapan, struktur gramatikal, fungsi atau isi, unsur, susunan, gaya penyajian (retorik), dan subjek. Peneliti menyarankan agar guru dapat menggunakan hasil penelitian ini sebagai bahan ajar ketika mengajar tentang frasa, klausa, dan kalimat. Guru tidak perlu kebingungan untuk mencari bentuk-bentuk frasa, klausa, dan kalimat karena dalam kajian ini sudah diberikan banyak contoh. Dengan demikian, hasil temuan ini sangatlah 
berkontribusi dalam menambah referensi guru pada saat mengajar.

\section{DAFTAR RUJUKAN}

Abduhzen, M. (2016). Mengayomi guru. Kompas. Halaman 6.

Alwi, H. (2003). Tata Bahasa Baku Bahasa Indonesia. Jakarta: Balai Pustaka.

Arifin, Z. (2008). Sintaksis: untuk Mahasiswa Strata Satu Jurusan Bahasa atau Lingustik dan Guru Bahasa Indonesia SMA/SMK. Jakarta: Grasindo.

Azra, A. (2016). Disorientasi religiointelektual. Kompas. Halaman 6.

Ba'dulu, A. M., \& Herman. (2005). Morfosintaksis. Jakarta: Rineka Cipta.

Baiq, P. (2015). Dilan. Bandung: Pastel Books.

Chaer. A. (2009). Sintaksis Bahasa Indonesia: Pedekatan Proses. Jakarta: Rineka Cipta.

Chomsky, N. (1957). Syntactic Structures. Berlin: Mouton de Gruyter.

Dahlan, M. (2017). Gorong-gorong Berita Bohong. Jawa Pos. Halaman 4.

Fajarwati, R. (2017). Kedai Bunga Kopi. Yogyakarta: Penerbit Araska.

Fitriani, D. (2015). Penguasaan Kalimat Efektif dan Penguasaan Diksi dengan Kemampuan Menulis Eksposisi Pada Siswa SMP. Jurnal Pesona. 1 (2) 129-139.
Fromkin, V., \& Robert, R. (1983). An Introduction to Language . New York: Holt, Rinehart dan Winston.

Ida, L. (2017). Korupsi Politik dalam Proyek E-KTP. Jawa Pos. Halaman 4.

Keraf, G. (1984). Tata Bahasa Indonesia. Edge Flores: Nusa Indah.

Kridalaksana, H. (2001). Kamus Linguistik. Edisi Ketiga. Jakarta: Penerbit PT Gramedia Pustaka Utama.

Kristianto, A. (2017). Jakarta, Pusat Masyarakat Madani. Jawa Pos. Halaman 4.

Lesmana, T. (2017). Relevansi Makar Pada Era Reformasi. Jawa Pos. Halaman 4.

Mahendra, Y.I. (2017). Pemisahan Agama dan Negara. Jawa Pos. Halaman 4.

Miles, M. B., \& Huberman, A. M. (2007). Analisis Data Kualitatif: Buku Sumber Tentang Metode-Metode Baru. Terjemahan Tjetjep Rohendi Rohidi. Jakarta: Universitas Indonesia Press.

Parker, F., \& Riley, K. (2005). Linguistics for Non-Linguists. Boston: Longman.

Permana, D. (2010). Fasa Nomina dalam Bahasa Banjar Samarinda. Jurnal Eksis. 6 (1): 1267-1266.

Putrayasa, I.B. (2009). Jenis Kalimat dalam Bahasa Indonesia. Bandung: Refika Aditama.

Rahmat, M. (2012). Struktur Frasa Endosentris Bahasa Buol di Desa Mokupo Kecamatan Karamat. FKIP Universitas Tadulako. 
Ramlan, M. (2005). Sintaksis. Yogyakarta: CV Karyono.

Rosliana, L. (2015) Frasa Endosentris pada Bahasa Jepang. Jurnal Azumi. 5 (1): 51-56.

Ruliati. (2015). Ketransitifan Verba dalam Bahasa Muna. Jurnal Humanika. 15 (3): 1-18.

Santoso, L. (2017). Menulis Buku, Menulis Kebenaran. Jawa pos. Halaman 4.

Septianingtias, V. (2015). Pola Kalimat pada Kumpulan Dongeng Gadis Korek Api Karya H.C. Andersen (Suatu Kajian Sintaksis). Jurnal Pesona. 1 (1):42-49.

Supriyadi. (2014). Sintaksis Bahasa Indonesia. Gorontalo: UNG Press.

Wahyono, M.R. (2017). Ekuinoks dan radiasi matahari. Jawa pos. Halaman 4.

Yersita. (2016). Sang Pencuri Warna. Yogyakarta: Diva Press. 